\title{
Antecedents of social media usage intensity in the financial sector of an emerging economy: a Pls-Sem Algorithm
}

\author{
John AMOAH \\ amoah@utb.cz \\ Felix NUTAKOR \\ School of Business, Qingdao University, China \\ Jinke LI \\ School of Business, Qingdao University, China \\ Abdul Bashiru JIBRIL \\ International University of Rabat, Rabat, Morocco \\ Benjamin SANFUL \\ Liaoning University, China \\ Michael Amponsah ODEI \\ Tomas Bata University in Zlin, Zlin, Czech Republic
}

Tomas Bata University in Zlin, Zlin, Czech Republic / Takoradi Technical University, Ghana

\begin{abstract}
The purpose of this paper is to offer a critical understanding of the motivations and benefits of social media usage by small and medium financial enterprises with an empirical study from an emerging economy such as Ghana. Based on previous studies, the current study hypothesizes that customer-firm relationship, financial expectation, firm's visibility and growth, and market share expectation drive social media usage intensity in the financial industry. Quantitative data was gathered from management and staff of SMEs, specifically, financial institution outlets (having social media channels i.e., Facebook, Instagram, YouTube, LinkedIn, etc.) was used to investigate the proposed conceptual framework. Using structural Equation Modelling, the research showed that customer-firm relationship, financial expectation, firm's visibility and growth, and market share expectation are positively associated with social media usage intensity within the financial sector. Moreover, it was discovered that financial firms that offer physical products only were equally employing social media networks for marketing communication purposes based on cost-effective motives. At the same time, we found that SMEs are more likely to consider 'market share expectation' as a key motivation for social media adoption by the financial industry. The findings from this study have provided some solutions to potential research issues specific to strategic management practices. Limitations and future research directions are discussed in the concluding remarks.
\end{abstract}

Keywords: Social media, financial industry, small- and medium-sized enterprises (SMEs), emerging market, low digitalized economy, Ghana.

Please cite the article as follows: Amoah, J., Nutakor, F., Li, J., Jibril, A. B., Sanful, B., Odei, M.A. (2021) "Antecedents of social media usage intensity in the financial sector of an emerging economy: a PlsSem Algorithm", Management \& Marketing. Challenges for the Knowledge Society, Vol. 16, No. 4, pp. 387-406, DOI: 10.2478/mmcks-2021-0023. 


\section{Introduction}

The constant evolution of information technology has helped in transforming businesses within the financial sector in emerging economies (Amoah et al., 2021; Belas et al., 2020). The high patronage of Internet use has also given customers a plethora of services on the web, resulting in a significant change in conducting business by financial firms. In recent times, social media have become spearhead platforms for building and managing both transactional and relational activities in financial firms and for managing and communicating brands (Dima \& Ghinea, 2016; Botchway et al., 2020; Jibril, Kwarteng, Chovancova, \& Vykydalova, 2019). The blooming nature of the financial sector in Ghana calls for more research across several business sectors and contexts in examining the need to adopt social media strategies and outcomes to develop theory. Several works of literature on social media assert that financial firms need to embrace social media to compete for a more significant market share and satisfy consumers (Jibril, Kwarteng, Chovancova, \& Pilik, 2019; Kwarteng et al., 2020; Jung et al., 2016). According to Amoah \& Jibril (2021), the financial sector in an emerging economy like Ghana has had a tremendous change due to the usage of social media, which has provided a systematic review of this growing concept. Despite social media's increasing popularity in the Sub-Saharan continent, however, literature exhibits some key deficiencies.

Firstly, discrepancies exist in previous studies with few findings generally based on a contextual framework (Jung et al., 2016). Hence, the need for further research to be conducted on the factors that have led to the increased usage of the said technology among the various subsectors of the financial industry. This could be interminable with the resurgence of financial applications in the business world. Secondly, from the small and medium-sized enterprises (SMEs) perspectives, few studies have been conducted based on the topic of this paper, especially from an emerging market such as Ghana (Odoom et al., 2017). Thirdly, critical scrutiny into varied literature on the adoption of social media marketing has been dominant across the advanced economies, while little is known across the financial sector in Ghana (Pettit, 2013). However, the advanced economies can boast of infrastructure and adequate resources to promote marketing campaigns on social media, which has been translated into increased revenue to succeed in the markets.

Interestingly, research into social media orientation has received a considerable attention across business and non-business organizations (Shen et al., 2019). Therefore, it has become very important for less developed economies such as Ghana to pay much attention to research on topical marketing issues, especially when it comes to the ICT orientation in the financial sector coupled with the influx of cybercrimes. An in-depth understanding and use of innovative means by SMEs would pave the way for marketing research (Odei \& Novak, 2020). Odei \& Stejskal (2020) argue that firms from advanced economies perform better than firms in emerging economies because advanced economies can quickly adopt technology whilst firms in the emerging economies are slow adopters of technology. In recent times, however, the financial industry has leveraged on social media in advertising their products and services in both developed and developing economies for a range of functions and helping to establish good customer relationships and a successful marketing communication. Some authors suggested that it is particularly useful for financial firms because it minimizes the cost of advertisement through print media, and even people with a low level of information technology skills can make good use of it (see Swani \& Brown, 2011). 
In an emerging economy such as Ghana, most financial SMEs do not have huge sums of money to meet the demands of their competitors, which limits their operations on the international level (Swani \& Brown, 2011; Smékalová, Hájek, Belás, \& Macháček, 2014; Belas, Gavurova, \& Toth, 2018). Furthermore, there is a sudden shift in media campaigns from the radio and televisions to the use of social media as an advertising campaign because social media helps both clients and customers in a prompt communication instead of customer review forms which are on the banking desk based on request. As a result, the financial sector adopting social media today presents an interesting path for firms' competitiveness, especially with its ability to offer a wide range of products and services to customers. The study, therefore, examines some leading factors contributing to the intensity of social media usage among financial institution outlets in Ghana. This research will help scholars and practitioners to better understand the benefits of social media usage and provide a justification for continued use and investments in social media by companies.

The structure of the paper is as follows. The next section discusses the theoretical context and literature review, the research model, and hypotheses for the study. The methodology section is therefore followed by the results, analyses, and discussions of findings. The paper concludes with some implications for theory and practice as well as provides some ways for further research.

\section{Theoretical setting of the study}

The concept of social media as innovation theory can be described as the adoption of modern technology in marketing, the development of products and services, and organizational development (Romer, 1990; Schumpeter, 2010). The adoption of social media as an innovation concept may be used in promoting new brands of products for financial institutions and small and medium enterprises. According to the proponents of innovation theory, major innovations can be distinguished by giving the firm a good competitive advantage over an existing method which paves the way for measurable but straightforward results. A study on the adoption and usage of technological innovation generally emerges from the concept of innovation theory (Akbar, 2021). Through the advocacy potentials which has given less attention to the print media and the traditional media, the adoption of social media as an internet-based technological approach has affirmed the concept of innovation. Social media has been a business support system for the financial sector in Ghana for various reasons in different contexts due to its marketing potentials which require less funding. The concept of social media is consequently defined based on this study by Kaplan \& Haenlein (2010) as an extension of print and traditional media, which uses simple technologies and techniques for social interactions. Therefore, new marketing techniques and strategies have been added to the old media broadcasting method, helping the financial sector without necessarily involving the media in their advertisement. The subsequent sections discuss the antecedents of social media usage and the various ways adopted by the financial industry influence their performance outcomes for SMEs.

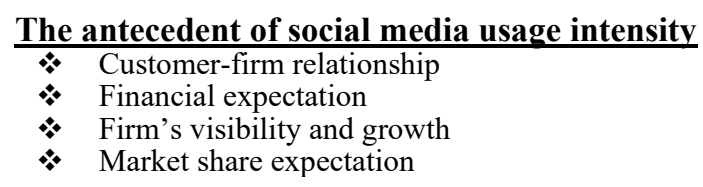

Figure 1. A proposed framework of antecedents of social media usage intensity. Source: Authors' idea. 


\section{Conceptual framework and propositions development: definitions of constructs \\ Overview of social media and financial services in Ghana}

Social media is a term used to refer to a wide range of internet-based and mobile services that allow users to participate in online exchanges, promote user-centred content or join communities (Afolabi et al., 2017). Social media is known to be a pivotal part that controls

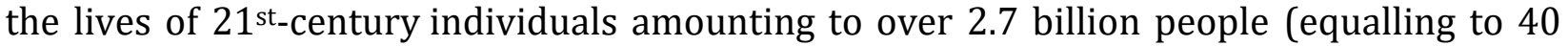
percent of the world's population) online, social media has transformed the ways of communication and information sharing (Gupta \& Vohra 2019). Citizens are progressively depending on social media for communication with their families, friends, colleagues, businesses, and the government. The capabilities to facilitate interpersonally and group interaction provide new and unique opportunities for community leaders, elected officials, and government service providers to inform and be informed by the citizenry (Golbeck et al., 2010; Kavanaugh et a., 2012; Dima \& Vasilache, 2016). A submission by Suvarna \& Banerjee, (2014) and corroborated by another report from Accenture (2014), identifies social media as a top drift in the banking industry. 89\% of customers surveyed had social media accounts, making it essential for the banking industry to strengthen the integration of social media with banking services. Clients via social media platforms can participate in activities such as opening bank accounts, accessing financial advice, transactions (e.g. bill payment, transfer funds, etc.), learning about new promotions, customer surveys, and getting real-time feedback on complaints and/or inquiries. Nițescu, (2015) stated that the emergence of social media and digital technologies have given rise to many alternative ways of conducting banking, permitting customers to gain access to all major operations. Afolabi et al., (2017) revealed that GT Bank (Nigeria) launched its innovative 'Social Banking' service on Facebook, being the first in Nigeria, with over 950,000 Facebook fans. Although the social account differs from a regular GT Bank account, the new channel allows GT Bank social account holders to transfer money, pay bills, buy airtime, and confirm their account balance on Facebook. As the social media trend grows, more banks and financial services providers including that of Ghana's are expected to strategically set up and maintain social media presence to engage their customers. Social media compliance and building customer relationships on it are not enough. There remain significant vulnerabilities to be managed regarding data security, privacy, legal and reputational risks (Odei et al., 2020).

\section{Social Media usage Intensity}

Social media usage intensity is a form of one's interest based on the quality and quantity designated by the individual. The intensity of the use of social media differs greatly for children, adolescents, and adults. However, considering the current situation, active users of social media are children of late teens or early adults aged 18-24 years. For instance, it was found that involvement with social networking through Internet can enhance the users' selfesteem while influencing their self-control. The enhancement in self-esteem may result in an individual's choice of placing themselves higher through the purchase of luxury goods online, thereby giving rise to consumers' indulgent behavior (Khan \& Dhar, 2006; Taqwa, 2018; Silmi et al., 2020). Word-of-mouth is considered a social force that has a heavy impact on consumers' purchase decisions. Some scholars have even debated that WOM is more influential than traditional marketing tools (Kozinets et al., 2010; Kumar \& Devi, 2014). 
Research reveals that social media users who have positive attitudes relationships with a brand are more likely to be involved in electronic word of mouth (e-WOM) about a particular brand (Chu \& Sung, 2015). Choi et al., (2018) stated that social media managers can detect users who are loyal to the brand and/or who use social media intensively, they can build a stronger relationship with them, leading them to spread more positive e-WOM to other users by providing quick responses to their questions, requests, and complaints. According to Zhang et al., (2018) when consumers read online reviews and advertisements, their (consumers) perceived higher quality and value for products generate an urge to buy impulsively. Clayton et al., (2015) revealed that cell phone separation has harmful effects on psychological outcomes (e.g. state anxiety), as well as increased heart rate and blood pressure. Makki et al., (2018) focused on Snapchat and discovered that the use of the social media platform was associated with individuals' innate will to be accepted, affiliated, and connected with others. Internet-enabled communication media has shadowed the traditional media and has supported many financial organizations in conducting their businesses from anywhere across the globe (Liberman et al., 2011). Jung et al. (2015), for instance, assert that social media has become part of human lives, and thus, there is a need for financial firms in Ghana to encourage Internet users for the development of the sector. According to Okazaki \& Taylor (2013) at the firm level, the use of social media among small and medium-sized companies especially in the financial sector has massively increased since 2012, with many users adopting the use of corporate Facebook pages and official corporate Twitter accounts, which aids in corporate blogs. There has been evidence that the Figures are on the increase each year (McCann \& Barlow, 2015).

\section{Customer-Firm Relationship}

The correlation between an organization and its clientele is what Kietzmann et al., (2011) referred to as "the new marketing" when customers give out their information through social media handles. According to (Soler-Labajos \& Jimenez, 2016; Metzker \& Zvarikova, 2021) having a strong bond with customers is the hallmark of good marketing. Peppers \& Rogers (2017) revealed that a key part of effective customer-firm relations is delivering pertinent information at the correct time and forming a personalized connection with the customer. It was established that social media have made it possible for Small Medium Enterprises to build customer-firm relationships, disseminate information at a reduced cost, and above all facilitate business connections with their customers (Amoah \& Jibril., 2021). Furthermore, Bailey et al. (2018) established that the adoption of social media has helped in establishing an effective feedback loop between an enterprise and its customers. Thus, instant feedback of responses is provided and received from customers of small and medium enterprises, while customers generate information to be circulated among other friends, organizations, and communities. Parveen et al., (2016) revealed that social media establishes a meaningful relationship between SMEs and their customers, builds upon customers' self-expressive brands, consumer participation, builds co-creative experiences. By this, we, therefore, hypothesize that;

Hypothesis 1(H1): customer-firm relationship would positively affect social media usage intensity in the financial sector. 


\section{Financial Expectation}

Social media innovations have improved an essential role in businesses and Small Medium Enterprise's performance in the past two decades. Some research on social media and its financial expectation perspective has been investigated in extant literature (Kim et al., 2016) though many gaps remain. Previous studies have investigated organizational usage, however only a few examined the impact of social media on organizational financial expectation. For example, Rodriguez et al., (2015) maintained that social media have extensively contributed to organizational sales and performance. This is achieved through social media customeroriented processes. Similarly, Kwok \& Yu (2013) concluded that social media increased sales volume and helped achieve the sales target of Small Medium Enterprises. The relationship between Small and Medium Enterprises and their potential consumers has received a magnificent improvement through social media and subsequently has affected SME's financial performance. The complete adoption of social media through its handlers like Twitter, Snapchat, Facebook, and others has complemented the financial weakness of SMEs and created opportunities to compete internationally. Importantly, social media handlers such as blogs (open diary), social networking (Facebook), and communities (YouTube) have helped organizations in achieving their financial targets. Pinho \& Soares, (2011) agreed that the exploitation of social media handles has impacted positively on SME's finances due to quality engagement organizations have with their clientele. Also, Amoah \& Jibril, (2021) affirmed that social media applications have contributed to the quality relationship between organizations (SMEs) and their customers, therefore, improving sourcing assistance and financial performance of SMEs. Hence, we propose that;

Hypothesis 2 (H2): Financial expectation by firms would positively affect social media usage intensity in the financial sector.

\section{Firm's Visibility and Growth}

Social media handles have offered opportunities to various categories of clients to share their concerns and experiences with audiences. Additionally, the emergence of social media has aided organizations in delivering quality services through competitive marketing using Competitive Intelligence (CI) advantage by connecting and identifying potential clientele (Afolabi et al., 2017; Tekin \& Turhan, 2021). According to Stephen, (2016), people spend a considerable amount of time online searching for information, on products and services communicating with other consumers about their experiences, and engaging with companies. It is currently revealed that organizations nowadays respond quickly to consumer behavior through the implementation of social media applications as an integral component of their business marketing plans. Companies via social media have the advantage to link up their clients, increase awareness of their products, influence consumer's behavior, welcome feedback, upgrade existing products and services, and multiply sales (Algharabat et al., 2018). As the social media trend grows, a lot more banks are expected strategically to establish and maintain social media presence to engage their clients (e.g. GT Bank Nigeria) and have utilized social media in advancing what is termed 'social banking', with a considerable followership base to enhance their firm's visibility and growth. In this light, we hypothesize that;

Hypothesis 3 (H3): A firm's visibility and growth would positively affect social media usage intensity in the financial industry. 


\section{Market Share Expectation}

There is an upsurge of increasing concern about how social media contribute to the market share of SMEs either positively or negatively. The answer to this lies in the ability of SMEs to critically access the perception of customers about their products and services based on shared information and experience (Tajvidi \& Karami, 2021). Besides, Jacobson et al., (2020) also established that consumers can access small and medium enterprises' products and services easily through social media without any difficulties and impediments. It was established that consumer satisfaction and experience are largely shared through recommendation, thus, encouraging customer-centeredness sales. According to Palmer et al., (2018), social media has aided SMEs ' marketing strategies. Lee et al., (2015) reveal that social media, Twitter, in particular, is becoming an important investor relation channel that firms can use to disclose information and enhance liquidity and transparency in financial markets. For instance, Cole et al., (2015) posited that per daily and monthly tweets of an organization have shown a positive correlation with its performance, as this tweeting factor further has impacted the activities of the shareholders positively. Abou-Elgheit (2018) stated that the increasing use of digital marketing and social media has positively influenced consumer attitudes toward online shopping with increasing market share for e-Commerce centric organizations. To this, we, therefore, propose that;

Hypothesis 4 (H4): Market share expectations would positively influence social media usage intensity in the financial sector.

\section{Materials and Methods Sampling and Procedure}

To fulfil the aim of this present study empirically, the quantitative research approach was adopted (Kurar, 2021). This approach was to help in testing the proposed research hypotheses. In going forward, a structured questionnaire was developed through Google forms which were in English. Both soft and hard copies of the questionnaire were distributed to some selected financial institutions that form part of the criteria. The protocols of Covid19 were duly observed during administering of a questionnaire at the premises of the selected respondents. The questionnaire was targeted at both employees and managerial staff of the financial institutions. The selection of these respondents was to obtain enough information to establish quality research results. The respondents' financial institutions were drawn from the Western and Central parts of the nation (Ghana). The selection of these regions was as a result of major financial and business activities been performed over there. Since all financial institutions from the selected regions cannot be involved in the data collection processes, a non-randomized (a combined purposeful-snowball) probability sampling technique was deployed in selecting the preferred financial institutions who are readily available to volunteer information in the filling of the questionnaire and to reduce time spent and money (Didkowska et al., 2021; Haseeb et al.,2019; Heckathorn, 2011). A questionnaire of 750 was distributed to the participants from selected financial institutions. A total of 655 questionnaires were returned of which 602 representing 91.91\% were good and correctly filled for the data processing/analysis. The data collection was carried out from June to September 2021. Each respondent used seven minutes' average to fill the structured questionnaire whilst they were advised not to indicate their particulars (names, addresses, etc) on the questionnaire for ethical standards of the study. Finally, the 602 valid responses received were processed and analyzed by the Partial Least Square-Structural Equation (PLS- 
SEM) through the adoption of the ADANCO 2.2.1 software version (Luvsandavaajav \& Narantuya, 2021). The below table shows the details of the respondents' summary and profiles.

Table 1. Demographic characteristics

\begin{tabular}{|c|c|c|c|}
\hline Variables & Details & Frequency & Percentage(\%) \\
\hline \multirow[t]{2}{*}{ Gender } & Male & 350 & 58.14 \\
\hline & Female & 252 & 41.86 \\
\hline \multirow{5}{*}{$\begin{array}{l}2 \\
2 \\
3 \\
4 \\
A\end{array}$} & $22-28$ & 150 & 24.92 \\
\hline & $29-35$ & 127 & 21.10 \\
\hline & $36-42$ & 148 & 24.58 \\
\hline & $43-49$ & 97 & 16.11 \\
\hline & Above 50 & 80 & 13.29 \\
\hline \multirow[t]{4}{*}{ Educational } & Senior High School & 82 & 13.62 \\
\hline & Diploma/HND & 125 & 20.76 \\
\hline & First Degree & 302 & 50.17 \\
\hline & Master's Degree & 93 & 15.45 \\
\hline \multirow[t]{4}{*}{ Company Size } & 1-50 employees & 60 & 9.96 \\
\hline & 51-100 employees & 137 & 22.76 \\
\hline & 101-300 employees & 135 & 22.43 \\
\hline & Above 300 & 270 & 44.85 \\
\hline \multicolumn{2}{|c|}{ Company's Location Western } & 375 & 62.29 \\
\hline \multirow{2}{*}{\multicolumn{2}{|c|}{ Working Experience $\quad 1-3$ years }} & 227 & 37.71 \\
\hline & & 322 & 53.49 \\
\hline \multicolumn{2}{|c|}{ 4-6 years } & 102 & 16.94 \\
\hline \multicolumn{2}{|c|}{ 7-9 years } & 96 & 15.95 \\
\hline \multirow{2}{*}{\multicolumn{2}{|c|}{$\begin{array}{c}10 \text { and above } \\
\text { Company Websites } \quad \text { Yes }\end{array}$}} & 82 & 13.62 \\
\hline & & 432 & 71.76 \\
\hline \multicolumn{2}{|c|}{ No } & 170 & 28.24 \\
\hline Information on & Yes & 458 & 76.08 \\
\hline Company's Websites & s No & 144 & 23.92 \\
\hline \multirow[t]{4}{*}{ Tools Used } & Wall Postings & 239 & 39.70 \\
\hline & Video & 132 & 21.93 \\
\hline & Pops-Ups & 28 & 4.65 \\
\hline & Photo Gallery & 203 & 33.72 \\
\hline
\end{tabular}

Sources: Authors' field survey, June-September 2021.

\section{Measurement of the constructs}

The measurement of the research constructs was taken from existing literature where a slight change was made in both measurements and constructs scale. A five-point Likert scale was adopted by the researchers $(1=$ strongly disagree, $2=$ disagree, $3=$ neutral, $4=$ agree and $5=$ strongly agree). The adoption of this scale was to obtain substantial information and also to assess the level of respondents' ideas from agreeing to disagree with the research constructs measurements.

\section{Data Analysis Technique}

The ADANCO 2.2.1 software version was deployed by the researchers through the Partial Least Square-Structural Equation Modeling (PLS-SEM) to execute the testing of the research model and hypotheses. The researchers adopted Partial Least Square-Structural Equation Modelling (PLS-SEM) since it does not require data to be normally distributed as in the case 
of Co-Variance-Based Structural Equation Modelling (CB-SEM). This means that the obtained statistical results are not contracted by non-normal data (Goodhue et al., 2012), therefore, the usage of PLS-SEM. According to (J. F. Hair et al., 2019; J. Hair et al., 2017), the use of the PLS-SEM approach by the researchers was a result of the explanation of the variance of the detailed variables and also appropriate to be used for exploratory studies. The proposed hypotheses were tested through ADANCO software version 2.2.1.

\section{Test of Common Method Bias}

In the quest to ascertain the presence of CMB (common method bias), the authors followed the research by Bagozzi \& Yi, (1988), in which the construct' items were carefully designed with description on the questionnaire' title page that respondents will be treated with strict confidence. Again, we performed a multicollinearity test to detect the presence of common method variance (CMV) of the scale measurements through the variance inflation factor (VIF). Again, CMV was not an issue of concern because the VIFs are less than five (5) taking into account the maximum threshold of ten (10) as revealed by (Haseeb et al.,2019; Su \& Cheng, 2019). Therefore, the details of the CMV are minimal as seen in the analysis (see in table 4).

\section{Empirical results}

According to the PLS-SEM literature of (Hair et al., 2019; Bagozzi \& Yi, 1988), the researchers were inspired to use Dijkstra-Henseler's rho along with Cronbach's alpha coefficients to assess the constructs reliabilities. From the below table, the minimum threshold of 0.5 indicating the strongest of the coefficients of the reliability of the construct were achieved as suggested by (Hair et al., 2019; Bagozzi \& Yi, 1988). The psychometric properties of the research constructs and their underlying items were vigorously evaluated by the software of the ADANCO 2.2.1 version (Henseler \& Dijkstra, 2015). On the composite reliability of the constructs, our analysis fulfils the requirements of Jöreskog's rho $(p c)$ and DijkstraHenseler's rho $(\rho A)$ with a minimum threshold of 0.7 and 0.8 respectively. Again, as suggested by Dijkstra-Henseler's rho $(\rho A)$, Cronbach's alpha $(\alpha)$ recorded a minimum reliability coefficient of 0.9198 and 0.9525 maximum respectively. The average variance extracted (AVE) presented the convergent validity, also exceeded the minimum threshold of 0.5 (see table 2 below)

Table 2. Construct reliability and validity

\begin{tabular}{lcccc}
\hline Constructs & $\begin{array}{c}\text { Dijkstra-Hensel's } \\
\text { rho (pA) }\end{array}$ & $\begin{array}{c}\text { Jöreskog's } \\
\text { rho (pc) }\end{array}$ & $\begin{array}{c}\text { Cronbach's alpha( } \boldsymbol{\alpha}) \\
\text { alpha }(\boldsymbol{\alpha})\end{array}$ & $\begin{array}{c}\text { The Average } \\
\text { Variance Extracted }\end{array}$ \\
\hline S.M Usage Intensity & 0.9320 & 0.9476 & 0.9308 & 0.7836 \\
Customer-firm Rela. & 0.9559 & 0.9602 & 0.9525 & 0.7513 \\
Financial Expectation & 0.9318 & 0.9529 & 0.9198 & 0.7574 \\
Firm's Vis. \& Growth & 0.9400 & 0.9481 & 0.9381 & 0.8019 \\
Mkt Share Expansion & 0.9281 & 0.9397 & 0.9270 & 0.8205 \\
\hline
\end{tabular}

To fully execute the factor loadings, all the latent variables of the research constructs were dully assessed and loaded in response to their respective constructs meaningfully. As established by Bagozzi \&Yi, (1998), a factor loading that is above the threshold of 0.6 is recognized as the best indicator of which the results obtained meet the requirements. As per 
the results of the table below, an indicator-variable loaded of (0.7922) and (0.9259) were obtained for the minimum and maximum respectively. Therefore, the details of the research constructs together with its items and their corresponding loadings (coefficients) are shown in Table 4 below.

Table 3. Variance Inflation Factors (VIFs) and Factor Loadings.

\begin{tabular}{|c|c|c|c|c|c|c|}
\hline \multicolumn{2}{|c|}{ Indicators VIF } & \multirow{2}{*}{$\begin{array}{c}\begin{array}{c}\text { Social media } \\
\text { usage Intensity }\end{array} \\
0.8740\end{array}$} & \multirow{2}{*}{$\begin{array}{c}\begin{array}{c}\text { Customer-Firm } \\
\text { Relationship }\end{array} \\
\end{array}$} & \multirow[t]{2}{*}{$\begin{array}{c}\text { Financial } \\
\text { Expectation }\end{array}$} & \multirow[t]{2}{*}{$\begin{array}{c}\text { Firm's Visibility } \\
\text { \& Growth }\end{array}$} & \multirow[t]{2}{*}{$\begin{array}{c}\text { Market Share } \\
\text { Expansion }\end{array}$} \\
\hline SMUI1 & 2.8385 & & & & & \\
\hline SMUI2 & 3.0387 & 0.8760 & & & & \\
\hline SMUI3 & 3.9485 & 0.9155 & & & & \\
\hline SMUI4 & 3.4643 & 0.9021 & & & & \\
\hline SMUI5 & 2.6735 & 0.8573 & & & & \\
\hline CFR1 & 2.7235 & & 0.8151 & & & \\
\hline CRF2 & 3.4092 & & 0.8565 & & & \\
\hline CRF3 & 4.7117 & & 0.9116 & & & \\
\hline CRF4 & 4.0647 & & 0.8953 & & & \\
\hline CRF5 & 3.9903 & & 0.8924 & & & \\
\hline CRF6 & 2.4767 & & 0.8112 & & & \\
\hline CRF7 & 3.7468 & & 0.8865 & & & \\
\hline CRF8 & 3.1183 & & 0.8595 & & & \\
\hline FE1 & 3.2843 & & & 0.8903 & & \\
\hline FE2 & 3.6629 & & & 0.9000 & & \\
\hline FE3 & 3.7478 & & & 0.9108 & & \\
\hline FE4 & 2.8949 & & & 0.8528 & & \\
\hline FE5 & 2.1959 & & & 0.7922 & & \\
\hline FVG1 & 3.1369 & & & & 0.8775 & \\
\hline FVG2 & 4.3538 & & & & 0.9250 & \\
\hline FVG3 & 3.8757 & & & & 0.8989 & \\
\hline FVG4 & 2.8949 & & & & 0.8869 & \\
\hline FVG5 & 3.8385 & & & & 0.9079 & \\
\hline MSE1 & 3.0722 & & & & & 0.8958 \\
\hline MSE2 & 3.8760 & & & & & 0.9259 \\
\hline MSE3 & 2.8445 & & & & & 0.8869 \\
\hline MSE4 & 3.4910 & & & & & 0.9140 \\
\hline
\end{tabular}

Note: 1- Social Media Usage Intensity, 2- Customer Firm Relationship, 3- Financial Expectation, 4- Firm's Visibility and Growth, 5-Market Share Expansion.

Source: Author's processing from ADANCO 2.2.1 version.

Nonetheless, the concern of explaining the discriminant validity of the constructs through the Fornell-Larcker's (1981) was seen to be appropriate. Therefore, FornellLarcker's (1981) was used to establish the discriminant validity between the latent variables (Henseler et al., 2015). More importantly, the values in the diagonal (in bold) of the FornellLarcker's in table 4 shows the Average Variance Extracted (AVE) of constructs measurements as suggested by experts (see Hair et al., 2019; Henseler et al., 2015) and also the diagonal values (in bold) exceeded the 0.5 requirements. To establish the discriminant validity, the construct's AVE must be a higher coefficient at column and row positions in connection with other constructs and therefore the results obtained satisfy both basic and stringent assumptions underlying it. 
Table 4. Test of Discriminant Validity - Fornell-Larcker Criterion

\begin{tabular}{llllll}
\hline Construct & $\begin{array}{l}\text { Social Media } \\
\text { Usage } \\
\text { Intensity }\end{array}$ & $\begin{array}{l}\text { Customer- } \\
\text { Firm } \\
\text { Relationship }\end{array}$ & $\begin{array}{l}\text { Firm's } \\
\text { Visibility \& } \\
\text { Growth }\end{array}$ & $\begin{array}{l}\text { Market Share } \\
\text { Expectation }\end{array}$ & $\begin{array}{l}\text { Financial } \\
\text { Expectation }\end{array}$ \\
\hline $\begin{array}{l}\text { 1=Social Media } \\
\text { Usage Intensity }\end{array}$ & $\mathbf{0 . 7 8 3 6}$ & & & \\
$\begin{array}{l}\text { 2=Customer- Firm- } \\
\text { Relationship }\end{array}$ & 0.6849 & $\mathbf{0 . 7 5 1 3}$ & & \\
$\begin{array}{l}\text { 3=Firm's } \\
\text { visibility } \\
\text { and Growth }\end{array}$ & 0.6487 & 0.6762 & $\mathbf{0 . 8 0 1 9}$ & \\
$\begin{array}{l}\text { 4=Market-Share- } \\
\text { Expectation }\end{array}$ & 0.5689 & 0.6453 & 0.7255 & $\mathbf{0 . 8 2 0 5}$ & $\mathbf{0 . 7 5 7 4}$ \\
$\begin{array}{l}\text { 5=Financial } \\
\text { Expectation }\end{array}$ & 0.4473 & 0.5394 & 0.5456 & 0.4824 & \\
\hline
\end{tabular}

Note: the diagonal (in bold) are the average variance extracted (AVE).

Sources: Author's processing from ADANCO 2.2.1 version.

\section{Structural modelling-Path analysis}

On the issue of model fit, structural modelling (path analysis) is also equally important and required in this study. The purpose of this analysis is significant since it establishes the relationship (causal-effect) of the study research constructs. Therefore, the empirical findings indicate that social media usage intensity by financial institutions has a significant impact on the constructs: Customer-Firm Relationship (CFR), Financial Expectation (FE), Firm's Visibility and Growth (FVG), and Market Share Expansion (MSE). The regression coefficients; Beta $(\beta)$, and the significant values; T-values $>1.96$ (or P-values $<0.05$ ) of these constructs are indicated in Table 5 . Concerning the coefficient of determination (predictive power) of the research model, the coefficient of determination of the regression model was assessed. The coefficient indicates the percentage of variation in the dependent variable that is been explained by the predictor (independent) variable. Thus, $\mathrm{R} 2$ of the predictive variable (Social Media Usage Intensity- SMUI) of 73\% is established (see Table 5 and Figure 2).

Table 5. Hypothetical path coefficient sources

\begin{tabular}{|c|c|c|c|c|c|c|c|}
\hline \multirow[t]{2}{*}{ Relationship } & \multicolumn{6}{|c|}{ Standard bootstrap results } & \multirow[b]{2}{*}{ Remarks } \\
\hline & Beta & Mean value & $\begin{array}{c}\text { SD } \\
\text { error }\end{array}$ & t-value & $\begin{array}{l}\text { Effect Size } \\
\left.\text { (Cohen's f }{ }^{2}\right)\end{array}$ & P-value & \\
\hline $\begin{array}{l}\text { Customer-firm } \\
\text { Rela->Social media } \\
\text { Usage intensity }\end{array}$ & 0.4832 & 0.4813 & 0.0620 & 7.7887 & 0.2296 & 0.0000 & Supported \\
\hline $\begin{array}{l}\text { Financial Expect-> } \\
\text { Social media } \\
\text { Usage intensity }\end{array}$ & 0.0184 & 0.0167 & 0.0364 & 0.5064 & 0.0005 & 0.3063 & Not supported \\
\hline $\begin{array}{l}\text { Vis. \& Growth-> } \\
\text { Social media } \\
\text { Usage intensity }\end{array}$ & 0.3406 & 0.3430 & 0.0668 & 5.1001 & 0.0901 & 0.0000 & Supported \\
\hline Market share Exp.-> & 0.0632 & 0.0636 & 0.0456 & 1.3844 & 0.0036 & 0.0833 & Not Supported \\
\hline $\begin{array}{l}\text { Social media usage } \\
\text { Intensity } \\
\text { Dependent Variabl }\end{array}$ & Coeffi & cient of deter & rmination & $\left(\mathrm{R}^{2}\right)$ & Adjusted R & & \\
\hline $\begin{array}{l}\text { Social media usage } \\
\text { intensity }\end{array}$ & & 0.7342 & & & 0.7326 & & \\
\hline
\end{tabular}




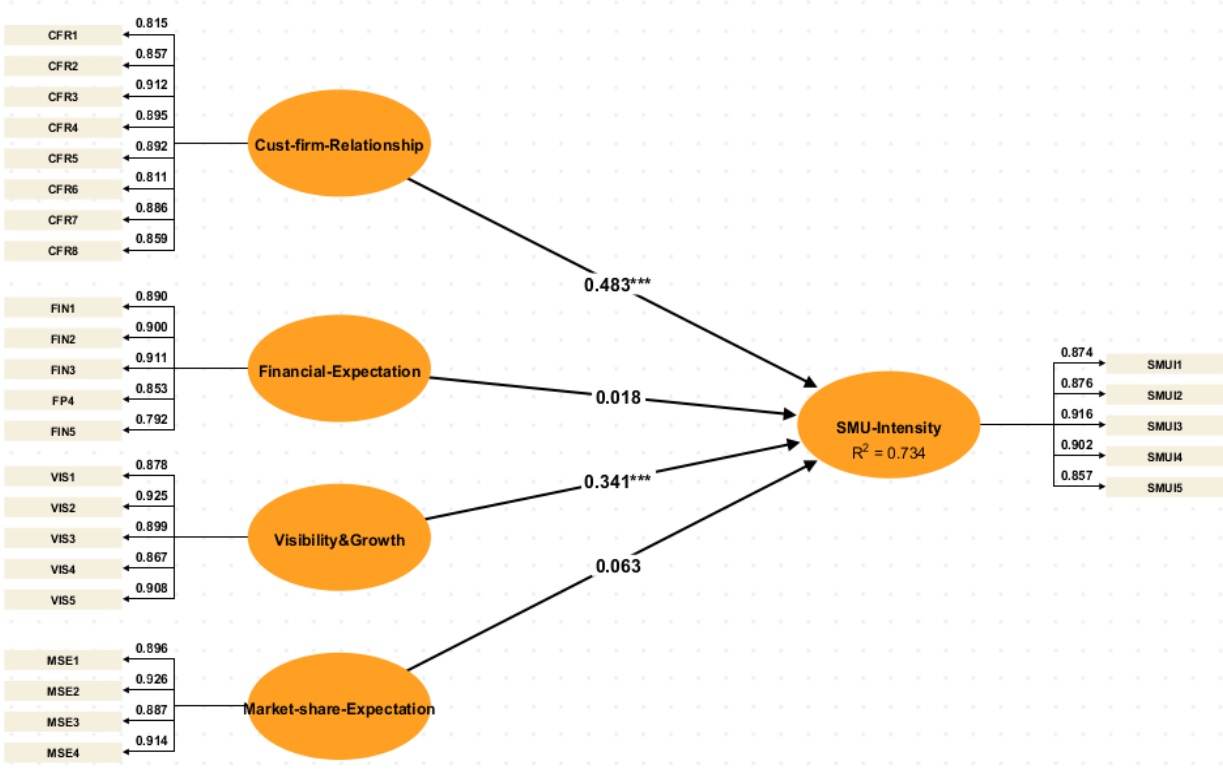

Figure 2. Empirically tested research Model.

\section{Discussion and Study Implications \\ General Discussion}

Findings revealed that social media usage intensity is crucial to promote the financial institution's activities and performance in devise ways. It is therefore established that the findings of the research do support that social media usage intensity has a positive relationship with the customer-firm relationship. Thus, the hypothesis (H1): customer-firm relationship positively and significantly affects social media usage in the financial sector is proven from the findings of the results. Again, the research outcome consequently relates positively to that of Chuang, 2020; Zhang et al., 2020; Nunan et al., 2018; Trainor et al., (2014) where it was established that the usage of social media networks by financial institutions has positively affected the interconnectivity between the customers, employees, and competitors of financial institutions. In this light, social media usage intensity has changed the communication channels of the relationship of financial institutions' day-to-day activities and has improved their information processing capabilities in recent times. Also, the relationship between customers and financial institutions in our modern-day has received a different dimension due to social media invention through the introduction of smartphones and has given rise to financial institutions to reconsider the approach of maintaining their customers at all times. It thus implies that financial institutions are capable of using social media to achieve the importance of customer-centric information processes and capabilities. Moreover, it is imperative to note that the application of social media networks by financial institutions placed a focus on customer interactions and information processes development which is likely to contribute and influence the customer-centric management systems success. Additionally, financial institutions can fully use social media to improve upon their customer-firm relationship and also facilitate the communication and responding to information obtained to support the development and modification of firm's products and services (Akhtar et al., 2018) while Tan et al., (2017) confirmed that social media usage intensity had helped financial institutions to holistically appreciate the needs and preferences of customers and respond to it quickly and that of market changes. Based on 
these findings, the researchers, therefore, opined that social media usage intensity by financial institutions would help maintain a quality business relationship between the firm and its customers since the dynamism of customer-firm relationships recently uphold a technological nature and the old system of dealing with customers.

Undoubtedly, the valid responses received for the data analysis of this study confirm that the hypothesis (H2): Financial expectation positively affects social media usage intensity in the financial sector is not supported by the findings of the current study. However, in the earlier works of Yahia et al., 2018; Amoah \& Jibril, 2021; Paniagua \& Sapena, (2014), it was affirmed that social media positively affect the financial expectations (monetary outcome) of most financial institutions depending on how it is used. Besides, the previous studies opined that social media usage has helped financial institutions to greatly achieve their sales and financial targets through its blogs (open diary), social networking (Facebook) among others. With this evidence, the current findings do not uphold the stated hypothesis (H2), yet it is believed that social media usage intensity can be of great help to financial institutions and ecommerce since prospective customers (particularly Gen Z) of financial institutions are interested in using it to access the firm's products and services in the postmodern era of transacting business.

Additionally, the proposed hypothesis (H3): A firm's visibility and growth positively affect social media usage intensity in the financial industry is strongly supported by the findings of the current study. This research thus agrees with the confirmed works of (Parveen et al., 2015; Benitez et al., 2020; Ali Qalati et al., 2021) that the usage of social media has tremendously created more benefits and opportunities for the financial institutions to consistently have more interactions and communications with its customers, therefore, affecting their visibility and growth positively. To add more, social media intensity has helped in creating company awareness, is customer-driven and subsequently reduces the cost of the firm's marketing campaign. With this scenario, the researchers believe that financial institutions adopting social media has helped them in building brand co-creation and loyalty among their customers and hence promote the firm in its innovative ways. Since the growth of an institution strongly depends on its choice of advertisements, financial institutions using social media has contributed to the creation of company awareness, promoting the company from different dimensions with minimal cost, reducing marketing campaign cost, and helps in awareness creation, creating a meaningful customer-driven product innovation.

Lastly, (H4): Market share expectation would positively influence social media usage intensity in the financial sector was not supported. However, there was a positive relationship between market share expectation and the intensity of social media usage, but statistically not significant. However, in the work of Cattedra, (2019) and Nepelski et al., (2020), it was confirmed that there is a positive relationship between market share expectation of financial institutions and social media usage. This study further suggests that, even though, there is a weak positive relationship between social media usage intensity and the expectation market share, firms could exploit other venues regarding their social media networks in which they can maximise the gains in their quest to intensify the usage of the technology.

\section{Theoretical relevance}

To researchers and potential researchers in the social media domain, the current study gives insights into the use of social media in the financial business context. This research examined the core antecedents of social media users regarding their impact on the performance of 
financial outlets in a developing economy. This study used social media-specific constructs, such as customer-firm relation, financial(revenue) expectation, firm's visibility, and market share to understand the intensity of social media usage among firms. The proposed framework of the study will again offer scholars the platform to unravel variables that trigger the intensive application of social media practitioners and owners of a company. This notwithstanding, add new evidence to the social media literature regarding its impact on business performance. In other words, this study contributed to the enrichment of the measurement of usage intensity, exclusively in the social media context. The research also evidently identifies the core antecedents of social media usage intensity on organizations (financial outlets) in terms of cost-effectiveness in financial marketing and customer service, enhanced firm-customer relations, and improved information accessibility and firm's product visibility.

\section{Practical relevance}

It is worth noting that organizational usage of social media is changing the mode of organizational communication and public relations. Under this, the technology (social media) enables open communication, which helps organizations to understand customer needs and motivates them to respond proactively and efficiently to those needs. By implication, technology is seen as a strategic management tool for practitioners and companies to adopt for successful marketing and advertisement of a company's product. It is also important to understand that globalization has technically defined the business environment as a 'global village', as such, digitalization is the only weapon for firms in the $21^{\text {st-century world to }}$ survive. Despite the negativities accompanied by the use of social media, this research provides enabling factors that motivate managers and decision-makers to understand the relevance of social media. This study informs them that proper and effective use of social media will improve the performance of the organization in various areas, as evidenced by the current study. For instance, the research findings indicated that social media usage has a significant correlation with organizations in terms of firm-customer relations and the firm's product visibility. Similarly, effective use of social media also improves revenue expectation and market share. Importantly, the evidence on the gains on social media usage motivates managers and marketing practitioners to provide initial and continuous support for the use of social media in organizations. Thus, decision-makers could leverage this study to strategize their mode of operation in terms of continuity and growth. Finally, the identified antecedents of social media usage intensity offered an insight to decision-makers in that they can concentrate on the key factors that are positively associated with social media usage.

\section{Conclusions, Limitations, and Future Research Directions}

The advent of digital marketing (electronic marketing) is no doubt the driving force of social media usage intensity. It is therefore imperative to note that the extant literature on IT (information technology) offers some instances of research investigating the determining factor of IT use and the degree of IT use and firm performance in today's businesses. Again, in the past few years, studies have been conducted to examine the antecedents and consequences of IT adoption in the various IT systems. However, in the context of social media usage intensity, there are insufficient studies that investigate organizational usage of social media intensity particularly in the financial industry of a low digitalized economy (such as Ghana). This study, hence, investigated the antecedents of social media usage in the 
financial outlets of Ghana which are within the categories of SMEs. To sum up, the study helps organizations to understand the benefits of social media usage and justifies continue use and investments in social media by companies. Again, the study has proven that, social media in Ghana has been used as an advertising tool for brand promotions which has created awareness for customer's and made competition keen among financial institutions. Marketing through social media has also reduced the rate at which financial institutions were attacked and robbed during face-to-face marketing and business to business. This study is not without limitations. Firstly, the study considered only financial institutions, hence it would be complex to generalize the study for all service-based organizations, even though such generalization could be done with caution. We, therefore, invite future researchers to undertake a comparative study across multiple organizations to validate and strengthen the reliability of the conceptual framework. Lastly, the study was purely quantitative which may suppress the in-depth knowledge regarding other factors that may be deemed relevant as antecedents of social media usage intensity. Hence, it would be interesting if future research could deploy a mixed approach for a similar inquiry.

Funding: This article was supported by the Internal Grant Agency of FaME, Tomas Bata University in Zlín, Project No. IGA/FaME/2020/005 and Humanities and Social Sciences of Ministry of Education Planning Fund (grant number: 15YJA630026), Shandong Soft Science Foundation (grant number: 2018RKB01302), Shandong Provincial Natural Science Foundation (grant number: ZR2020MG034), Shandong Social Science Foundation (grant number: 18CLYJ20).

\section{References}

Abou-Elgheit, E. (2018). Understanding Egypt's emerging social shoppers. Middle East Journal of Management, 5(3), 207-270.

Afolabi, I. T., Ezenwoke, A. A., \& Ayo, C. K. (2017). Competitive analysis of social media data in the banking industry. International Journal of Internet Marketing and Advertising, 11(3), 183-201.

Algharabat, R., Rana, N. P., Dwivedi, Y. K., Alalwan, A. A., \& Qasem, Z. (2018). The effect of telepresence, social presence, and involvement on consumer brand engagement: An empirical study of non-profit organizations. Journal of Retailing and Consumer Services, 40, 139-149.

Akbar, A. (2021). Factors influencing the usage of Instagram for business and its effect on financial performance and non-financial performance. Journal of Digitovation and information system, 1(1), 43-55.

Ali Qalati, S., Li, W., Ahmed, N., Ali Mirani, M., \& Khan, A. (2021). Examining the factors affecting SME performance: the mediating role of social media adoption. Sustainability, 13(1), 75.

Amoah, J., \& Jibril, A. B. (2021). Social Media as a Promotional Tool Towards SME's Development: Evidence from the Financial Industry in a Developing Economy. Cogent Business \& Management, 8(1), 1923357.

Amoah, J., Jibril, AB, Luki, BN, Odei, MA \& Yawson, C. (2021). Barriers of SMEs' sustainability in sub-Saharan Africa: a pls-sem approach. International Journal of Entrepreneurial Knowledge, 9 (1), 10-24. International Journal of Entrepreneurial Knowledge, 9(1), 10-24. 
Akhtar, P., Khan, Z., Tarba, S., \& Jayawickrama, U. (2018). The Internet of Things, dynamic data and information processing capabilities, and operational agility. Technological Forecasting and Social Change, 136, 307-316.

Bailey, A. A., Bonifield, C. M., \& Arias, A. (2018). Social media use by young Latin American consumers: An exploration. Journal of Retailing and Consumer Services, 43, 10-19.

Bagozzi, R. P., \& Yi, Y. (1988). On the evaluation of structural equation models. Journal of the academy of marketing science, 16(1), 74-94.

Benitez, J., Ruiz, L., Castillo, A., \& Llorens, J. (2020). How corporate social responsibility activities influence employer reputation: The role of social media capability. Decision Support Systems, 129, 113223.

Belas, J., Amoah, J., Petráková, Z., Kliuchnikava, Y., \& Bilan, Y. (2020). Selected Factors of SMEs Management in the Service Sector. Journal of Tourism and Services, 21(11), 129-146. https://doi.org/10.29036/jots.v11i21.215.

Belas, J., Gavurova, B., \& Toth, P. (2018). Impact of selected characteristics of SMEs on the capital structure. Journal of Business Economics and Management, Volume: 19, Issue: 4, pp. 592-608. https://doi.org/10.3846/jbem.2018.6583.

Cattedra, M. (2019). Global Marketing How to identify an international business opportunity in Italian SMEs from the agri-business sector: The case of Tortella in the USA market (pp. 1-50). Luiss Guido Carli.

Clayton, R. B., Leshner, G., \& Almond, A. (2015). The extended iSelf: The impact of iPhone separation on cognition, emotion, and physiology.Journal of Computer-Mediated Communication, 20(2), 119-135.

Choi, Y., Thoeni, A., \& Kroff, M. W. (2018). Brand actions on social media: Direct effects on electronic word of mouth (eWOM) and moderating effects of brand loyalty and social media usage intensity. Journal of Relationship Marketing, 17(1), 52-70.

Chu, S. C., \& Sung, Y. (2015). Using a consumer socialization framework to understand electronic word-of-mouth (eWOM) group membership among brand followers on Twitter. Electronic Commerce Research and Applications, 14(4), 251-260.

Chuang, S. H. (2020). Co-creating social media agility to build strong customer-firm relationships. Industrial Marketing Management, 84, 202-211.

Cole, B., Daigle, J., \& Van Ness, B. F. (2015). Do Tweets Matter for Shareholders? An Empirical Analysis. Journal of Accounting \& Finance (2158-3625), 15(3).

Didkowska, A., Ptak, M., Opałczyńska, K., Wojciechowska, M., Olech, W., \& Anusz, K. (2021). A Serological Survey of Paratuberculosis in the Polish European Bison (Bison bonasus) Population in 2018-2021. Animals, 11(7), 2094.

Dima, A.M. and Ghinea, V. (2016). A model of academic leadership. in Pinzaru, F. and Bratianu, C. (eds.). Proceedings of the 12th European Conference on Management, Leadership, and Governance, 10-11 November 2016, SNSPA, Bucharest, Romania, Academic Conferences and Publishing International Reading.

Dima, M.A. and Vasilache, S. (2016). Trends in the internationalization of European higher education in a convergence perspective. Management \& Marketing. Challenges for the Knowledge Society, Vol. 11, No. 2, 449-457, DOI: 10.1515/mmcks-2016-0008.

Goodhue, D. L., Lewis, W., \& Thompson, R. (2012). Does PLS have advantages for small sample size or non-normal data? Mis Quarterly (pp. 981-1001). JSTOR.

Golbeck, J., Grimes, J. M., \& Rogers, A. (2010). Twitter use by the US Congress. Journal of the American Society for information science and technology, 61(8), 1612-1621 
Gupta, G., \& Vohra, A. V. (2019). Social Media Usage Intensity: Impact Assessment on Buyers' Behavioural Traits. FIIB Business Review, 8(2), 161-171.

Haseeb, M., Hussain, H. I., Kot, S., Androniceanu, A., \& Jermsittiparsert, K. (2019). Role of social and technological challenges in achieving a sustainable competitive advantage and sustainable business performance. Sustainability, 11(14), 3811.

Hair, J. F., Risher, J. J., Sarstedt, M., \& Ringle, C. M. (2019). When to use and how to report the results of PLS-SEM. European business review.

Henseler, J., Ringle, C. M., \& Sarstedt, M. (2014). A new criterion for assessing discriminant validity in variance-based structural equation modeling. Journal of The Academy of Marketing Science, 43(1), 115-135.

Heckathorn, D. D. (2011). Comment: Snowball versus respondent-driven sampling. Sociological Methodology, 41(1), 355-366. https://doi.org/10.1111/j.1467-9531. 2011.01244.x.

Jacobson, J., Gruzd, A., \& Hernández-García, Á. (2020). Social media marketing: Who is watching the watchers? Journal of Retailing and Consumer Services, 53, 101774.

Jung, J., Shim, S. W., Jin, H. S., \& Khang, H. (2016). Factors affecting attitudes and behavioral intention towards social networking advertising: a case of Facebook users in South Korea. International Journal of Advertising, 35(2), 248-265.

Kaplan, A. M., \& Haenlein, M. (2010). Users of the world, unite! The challenges and opportunities of Social Media. Business Horizons, 53(1), 59-68.

Kavanaugh, A. L., Fox, E. A., Sheetz, S. D., Yang, S., Li, L. T., Shoemaker, D. J., ... \& Xie, L. (2012). Social media use by the government: From the routine to the critical. Government Information Quarterly, 29(4), 480-491.

Khan, U., \& Dhar, R. (2006). Licensing effect on consumer choice. Journal of marketing research, 43(2), 259-266.

Kietzmann, J. H., Hermkens, K., McCarthy, I. P., \& Silvestre, B. S. (2011). Social media? Get serious! Understanding the functional building blocks of social media. Business Horizons, 54(3), 241-251.

Kim, W. G., Li, J. J., \& Brymer, R. A. (2016). The impact of social media reviews on restaurant performance: The moderating role of excellence certificate. International Journal of Hospitality Management, 55, 41-51.

Kozinets, R. V., De Valck, K., Wojnicki, A. C., \& Wilner, S. J. (2010). Networked narratives: Understanding word-of-mouth marketing in online communities. Journal of Marketing, 74(2), 71-89.

Kumar, K. V., \& Devi, V. R. (2014). Social media in financial services - a theoretical perspective. Procedia Economics and Finance, 11, 306-313.

Kurar, İ. (2021). Research in the determination of recreational experience preferences, expectations, and satisfaction levels of local people. Reference: Kurar, İ. (2021).

Kwok, L., \& Yu, B. (2013). Spreading social media messages on Facebook: An analysis of restaurant business-to-consumer communications. Cornell Hospitality Quarerly, 54(1), 84-94.

Luvsandavaajav, 0., \& Narantuya, G. (2021). Understanding of Travel Motivations of Domestic Tourists: Reference: Oyunchimeg, L. \& Gantuya, N. (2021). Understanding of Travel Motivations of Domestic Tourists. Journal of Tourism and Services, 22 (12), $1-22$. 
Lee, L. F., Hutton, A. P., \& Shu, S. (2015). The role of social media in the capital market: Evidence from consumer product recalls. Journal of Accounting Research, 53(2), 367-404.

Liberman, B., Seidman, G., McKenna, K. Y., \& Buffardi, L. E. (2011). Employee job attitudes and organizational characteristics as predictors of cyberloafing. Computers in Human Behavior, 27(6), 2192-2199.

Makki, T. W., DeCook, J. R., Kadylak, T., \& Lee, O. J. (2018). The social value of Snapchat: An exploration of affiliation motivation, the technology acceptance model, and relational maintenance in Snapchat use. International Journal of Human-Computer Interaction, 34(5), 410-420.

McCann, M., \& Barlow, A. (2015). Use and measurement of social media for SMEs. Journal of small business and enterprise development.

Metzker, Z., \& Zvarikova, K. (2021). The Perception of Company Employees by SMEs with CSR Concept Implementation. International Journal of Entrepreneurial Knowledge, 9(1), 81-96. doi:10.37335/ijek.v9i1.128.

Nepelski, D., \& Van Roy, V. (2020). Innovation and innovator assessment in R\&I ecosystems: The case of the EU Framework Programme. Journal of Technology Transfer. https://doi.org/10.1007/s10961-020-09814- 5.

Nițescu, D. C. (2015). Banking Business and Social Media-A Strategic Partnership. Theoretical \& Applied Economics, 22(4).

Nunan, D., Sibai, O., Schivinski, B., \& Christodoulides, G. (2018). Reflections on "social media: Influencing customer satisfaction in B2B sales" and a research agenda. Industrial Marketing Management, 75, 31-36.

Odei, M. A., \& Novak, P. (2020). Appraisal of the factors contributing to European small and medium enterprises innovation performance. Problems and Perspectives in Management.

Odei, S. A., \& Stejskal, J. (2020). Firms pursuit of innovations through internationalization: a treatment effect estimation. Technological and Economic Development of Economy, 26(4), 837-866.

Odei, S. A., Odei, M. A., \& Anderson Jr, H. (2020). Consultants and firm-level innovation performances: a doubly robust estimation approach. Eastern Journal of European Studies.

Odoom, R., Anning-Dorson, T., \& Acheampong, G. (2017). Antecedents of social media usage and performance benefits in small-and-medium-sized enterprises (SMEs). Journal of Enterprise Information Management.

Okazaki, S., \& Taylor, C. R. (2013). Social media and international advertising: theoretical challenges and future directions. International marketing review.

Paniagua, J., \& Sapena, J. (2014). Business performance and social media: Love or hate? Business Horizons, 57(6), 719-728.

Parveen, F., Jaafar, N. I., \& Ainin, S. (2015). Social media usage and organizational performance: Reflections of Malaysian social media managers. Telematics and informatics, 32(1), 67-78.

Palmer, K., Tate, J. E., Wadud, Z., \& Nellthorp, J. (2018). The total cost of ownership and market share for hybrid and electric vehicles in the UK, US, and Japan. Applied energy, 209, 108-119. 
Pettit, A. (2013). Identifying the real differences of opinion in social media sentiment. International Journal of Market Research, 55(6), 757-767.

Peppers, D., \& Rogers, M. (2017). Evolution of relationships with customers and strategic customer experiences. Managing Customer Relationships, 627.

Pinho, J. C. M. R., \& Soares, A. M. (2011). Examining the technology acceptance model in the adoption of social networks. Journal of research in Interactive Marketing.

Rauniar, R., Rawski, G., Yang, J., \& Johnson, B. (2014). Technology acceptance model (TAM) and social media usage: an empirical study on Facebook. Journal of Enterprise Information Management.

Romer, P. M. (1990). Endogenous technological change. Journal of Political Economy, 98(5, Part 2), S71-S102.

Rodriguez, M., Peterson, R. M., \& Ajjan, H. (2015). CRM/social media technology: impact on customer orientation process and organizational sales performance. In Ideas in Marketing: Finding the new and polishing the old, 636-63, Springer, Cham.

Schumpeter, J. A. (2010). Capitalism, socialism, and democracy. Routledge.

Smékalová, L., Hájek, O., Belás, J., \& Macháček, J. (2014). Perception of Small and Medium Entrepreneurship in the Czech Republic. Journal of Competitiveness, Vol. 6, Issue 4, 41-49. https://doi.org/10.7441/joc.2014.04.03.

Swani, K., \& Brown, B. P. (2011). The effectiveness of social media messages in organizational buying contexts. In American Marketing Association, Vol. 22, p. 519.

Shen, L., Zhang, C., \& Teng, W. (2019). The double-edged effects of guanxi on partner opportunism. Journal of Business \& Industrial Marketing.

Sheth, J. N. (2011). Impact of emerging markets on marketing: Rethinking existing perspectives and practices. Journal of Marketing, 75(4), 166-182.

Silmi, Z. K., Rachmawati, W. R., Sugiarto, A., \& Hastuti, T. P. (2020). Correlation of Intensity of Use of Social Media with The Level of Social Anxiety in Adolescents. Midwifery and Nursing Research, 2(2), 60-64.

Soler-Labajos, N., \& Jiménez-Zarco, A. I. (2016). Social CRM: The role of social media in managing customer relations. In Managing Public Relations and Brand Image through Social Media, 134-159. IGI Global.

Stephen, A. T. (2016). The role of digital and social media marketing in consumer behavior. Current Opinion in Psychology, 10, 17-21.

$\mathrm{Su}$, C. H., \& Cheng, T. W. (2019). A sustainability innovation experiential learning model for virtual reality chemistry laboratory: An empirical study with PLS-SEM and IPMA. Sustainability, 11(4), 1027.

Taqwa, M. I. (2018). Intensitas Penggunaan Media Sosial Instagram Stories Dengan Kesehatan Mental (Doctoral dissertation, University of Muhammadiyah Malang).

Tajvidi, R., \& Karami, A. (2021). The effect of social media on firm performance. Computers in Human Behavior, 115, 105174.

Tekin, O. A., \& Turhan, A. A. (2021). Does Social Media Addiction Differ by Personality Traits? A Study on Undergraduate Tourism Students. Journal of Tourism and Services, 22 (12), 23-41.

Trainor, K. J., Andzulis, J. M., Rapp, A., \& Agnihotri, R. (2014). Social media technology usage and customer relationship performance: A capabilities-based examination of social CRM. Journal of business research, 67(6), 1201-1208. 
Tan, F. T. C., Tan, B., Wang, W., \& Sedera, D. (2017). IT-enabled operational agility: An interdependencies perspective. Information \& Management, 54(3), 292-303.

Yahia, I. B., Al-Neama, N., \& Kerbache, L. (2018). Investigating the drivers for social commerce in social media platforms: Importance of trust, social support, and the platform perceived usage. Journal of Retailing and Consumer Services, 41, 11-19.

Zhang, H., Gupta, S., Sun, W., \& Zou, Y. (2020). How does social-media-enabled co-creation between customers and the firm drives business value? The perspective of organizational learning and social Capital. Information \& Management, 57(3), 103200.

Zhang, K. Z., Xu, H., Zhao, S., \& Yu, Y. (2018). Online reviews and impulse buying behavior: the role of browsing and impulsiveness. Internet Research. 